\title{
Comparative Assessment of Wines Developed from Different Varieties of Oranges
}

\author{
V. A. Athira and V. R. Sinija* \\ Food Processing and Business Incubation Centre, Indian Institute of Food Processing \\ Technology, Thanjavur (TN), India \\ *Corresponding author
}

\section{A B S T R A C T}

\begin{tabular}{|l|}
\hline Ke y w or d s \\
Wine, Orange, \\
Kinnow, Mandarin \\
\hline Article Info \\
\hline $\begin{array}{l}\text { Accepted: } \\
\text { 25 December } 2020 \\
\text { Available Online: } \\
\text { 10 January } 2021\end{array}$ \\
\hline
\end{tabular}

Genotype variations of agricultural commodities may cause variation in physicochemical properties of products prepared out of these commodities. However, the data was not validated for the wines developed with various orange varieties. By taking this point into consideration, this study was aimed to analyse the quality of the wine developed from different orange varieties. The wines were developed and analysed for different physicochemical, phytochemical and sensory properties. Among developed samples, citrus wine showed better quality parameters such as Vit. C, TPC, antioxidant activity and alcohol content with values of $120.81 \pm 3.05 \mathrm{mg} / 100 \mathrm{~mL}, 151.62 \pm 1.28 \mathrm{GAE} / \mathrm{ml}, 85.62 \pm 0.79 \%$ and $14.94 \pm 0.3 \%$ respectively. The commercial wine followed orange wine for antioxidant activity $(80.52 \pm 1.79 \%)$ this may be due to higher TPC content $(137.54 \pm 0.34 \mathrm{GAE} / \mathrm{ml})$. The alcohol content of developed wine was found to be higher in comparison with commercial wine $(11.86 \pm 0.2 \%)$. These results can be backed by lower amount of reducing sugars in the developed wine and the lowest was found in orange wine $(23.25 \pm 0.48$ $\mathrm{mg} / \mathrm{ml}$ ). Based on sensory analysis, wine developed with orange showed highest acceptance after commercial wine.

\section{Introduction}

India stands second in the world in production of fruits with 99.07 million metric tonnes production during 2019-20 (National Horticulture Board, 2021).Among these produce, citrus fruit is an important group of fruit belonging to the family Rutaceae. The Rutaceae family includes lime or lemon, orange, mandarin, tangerine, clementine, satsuma, etc. Citrus fruits are cultivated in tropical and sub-tropical regions of the world, especially in the USA, Brazil, and China. Among various citrus species, mandarins, lime/ lemons, and sweet oranges are cultivated more in India which occupies 41,25, and 20 percent of the total area respectively (Yadav, 2019). These fruits are popular due to their excellent flavour and nutritional value.

Mandarin fruit (Citrus reticulata) occupy an area of 428 thousand ha with an annual production of 51.01 lakh metric tonnes in the 
country (Anon, 2017). It is commercially cultivated in the specific regions of the country like 'Nagpur' mandarin in central India, 'Khasi' mandarin in northeastern regions, and 'Coorg' mandarin in southern parts of the country. Kinnow the hybrid variety of Citrus nobilis and Citrus deliciosa also known as "king" and "Willow Leaf" mandarin respectively developed at the University of California Citrus Experiment Station in 1935 and was introduced in early 1940 in India (Mahawar, Bibwe, Jalgaonkar, \& Ghodki, 2019). It is refreshing and nutritional due to its sweet: acid taste, vitamin ' $\mathrm{C}$ ' and minerals ( $\mathrm{Ca}, \mathrm{P} \& \mathrm{Fe}$ ) content, and appealing color (Ladaniya, 2008). Kinnow juice is also rich in nutrients such as ascorbic acid (53mg/100g), flavonoids, limonoids, and essential vitamins which includes Folates of $30 \mu \mathrm{g}$, Niacin $0.282 \mathrm{mg}$, Panthothenic acid $0.25 \mathrm{mg}$, Pyridoxine $0.060 \mathrm{mg}$, Riboflavin $0.040 \mathrm{mg}$, Thiamine $0.1 \mathrm{mg}$, Vitamin A $(225$ IU), Vitamin E (0.18mg) per 100g. These fruits also contain electrolytes; potassium 300 $\mathrm{mg}$ in $178 \mathrm{ml}$ juice), minerals such as calcium $40 \mathrm{mg}$, copper $39 \mathrm{mg}$, iron $0.1 \mathrm{mg}$, magnesium $10 \mathrm{mg}$, manganese $0.024 \mathrm{mg}$, zinc $0.8 \mathrm{mg}$ and $\beta$-carotenoids $71 \mu \mathrm{g}$ per $100 \mathrm{~g}$ (USDA National Nutrient Database 2018). Due to the presence of these nutrients, Kinnow has antispasmodic, sedative, cytophylactic, digestive, anticarcinogenic, anti-inflammatory, and antiallergic effects. Kinnow fruit production is high compared to other citrus fruits in India. Kinnow fruit production covers almost $3.61 \times 10^{\wedge} 5$ ha (Contreras et al., 2014).

The sweet orange (Citrus sinensis L. Osbeck) is one of the most important commercially cultivated fruit crops of Citrus and occupies the second position after mandarins in India. Among the cultivated species, $C$. sinensis (L.) Osbeck (sweet orange) is the most important commercial fruit crop of Citrus and occupies the second position after mandarins in India. C. sinensis is believed to be a hybrid between pummelo (Citrus maxima) and mandarin (Citrus reticulata) (Malik et al., 2012).

Despite larger production, almost 35 to $40 \%$ of the total produce get wasted at various levels (Hegazy, 2013). In previous decade, Indian food processing industry was utilizing fewer than $2 \%$ of total produce. Though the rate of processing is increasing till 8-10\% in recent time, it is found short to coup with the losses. So, it becomes more important to seek for the better ways to utilize the produce in better and sustainable way.

Wine is an undistilled alcoholic beverage produced by fermentation technique. Fruit juice undergoes fermentation differs in physicochemical and sensory qualities, at the same time it has preservation effect also (Swami, Thakor, \& Divate, 2014). Tropical fruits can be used as a surface or substance on which yeast grows for wine fermentation. As a fermented and undistilled product based on fruit, wine contains most of the nutrients contained in the original fruit juice. Owing to the release of amino acids and other nutrients from yeast during fermentation, the nutritive value of wine is increased. Wine is a fruit product, but a number of chemical compounds are formed by yeast during fermentation as their metabolites along with alcohol and $\mathrm{CO}_{2}$. Changes in the must, and so wine with ethanol added is far from being juice. Both clinical and experimental data indicate that moderate red wine consumption provides greater health safety by reducing cardiovascular morbidity and mortality, and this is due to antioxidant polyphenolics, especially found in red grape wine (Saranraj, Sivasakthivelan and Naveen, 2017).

There are many factors that determine the quality of the final produce. Substrate related factors such as cultivar types, cultivation conditions at harvest, and post-harvest handling etc, plays a major role in final 
product quality (Okunowo and Osuntoki, 2007). The main objective of the current topic is the physicochemical evaluation and functional properties comparison of wines developed from different varieties of oranges (Citrus reticulate, Citrus sinensis, and kinnow) with the commercially available wine.

\section{Materials and Methods}

\section{Materials and chemicals}

Kinnow fruits harvested during October were purchased from Punjab, India, and stored at $14^{\circ} \mathrm{C}$ under cold storage. The mandarin and orange were procured from Nagpur, Maharashtra. Other material required for experiment were procured from local market of Thanjavur. The chemicals used for these experiments were of analytical grade purchased from Himedia (Nasik, India).

\section{Inoculum preparation}

Saccharomyces cerevisiae NCIM3594 was collected from the National Collection of Industrial Microorganism, Pune, India. Yeast extract peptone dextrose (YEPD) media was used for culturing and reactivating the yeast. $100 \mathrm{ml}$ media was prepared in a $150 \mathrm{ml}$ conical flask. The conical flask with media was sterilized before inoculating the organisms in an autoclave for 20 minutes at $121^{\circ} \mathrm{Cand} 15$ psi pressure.

The yeast cells were inoculated into the media. Further, the inoculum was placed in a shaking incubator for 2 days at $30^{\circ} \mathrm{C}$ and sterile conditions were maintained. For retrieving yeast cells from the media, it was centrifuged at $5000 \mathrm{rpm}$ for $25^{\circ} \mathrm{C}$. After discarding the supernatant, yeast cell pellets were diluted to $1.2 \times 10^{6}$ cells $/ \mathrm{mL}$ (starter culture) by washing using sterile distilled water.

\section{Juice extraction}

The juice were extracted by using colloidal ball mill. The peels of the fruits were removed after washing it properly. After extracting juice using colloidal ball mill, it was filtered by using muslin cloth. After addition of 700 ppm KMS per litre of the fruit juice keep it for 24 hours (Saranraj et al., 2017).

\section{Fermentation}

The TSS of the fruit juices was adjusted to $20^{\circ}$ Brix by adding sugar. After the inoculation of $10 \% \mathrm{v} / \mathrm{v}, 1.2 \times 10^{6}$ per $\mathrm{ml}$ Saccharomyces cerevisiae under sterile conditions, the juice was kept for fermentation under $25^{\circ} \mathrm{C}$ in a bioreactor provided with continuous stirring action at $150 \mathrm{rpm}$. The wine produced by the fermentation reaction was clarified after attaining a constant TSS. Minimum 7 days was observed to finish the fermentation. The fermented wine was centrifuged at $10000 \mathrm{rpm}$ for the clarification process.

\section{Quality analysis of developed wine}

\section{Alcohol content}

Alcohol percentage was determined by the Dichromate-spectrophotometric method (Miller,1959). $3 \mathrm{ml}$ of the sample was transferred to $100 \mathrm{ml}$ distillation flask and was diluted with $30 \mathrm{ml}$ distilled water and keep it for 20 minutes in the distillation unit at $70-80^{\circ} \mathrm{C}$. Collect the distillate in $50 \mathrm{ml}$ flask containing $25 \mathrm{ml}$ potassium dichromate solution. Transfer this to a water bath which is maintained at $60^{\circ} \mathrm{C}$ for 20 minutes. After attaining room temperature the volume was made up to $50 \mathrm{ml}$ using distilled water to measure the absorbance at $600 \mathrm{~nm}$ using a spectrophotometer. Total alcoholic content (\%) can be calculated from a calibration curve using ethanol as the standard. 


\section{Antioxidant activity}

The antioxidant activity was measured by using DPPH free radical scavenging activity (Hayat, Abbas, Jia, Xia, \& Zhang, 2011). Different concentrations of wine were taken in clean test tubes, to this $2 \mathrm{~mL}$ of DPPH solution were added. The tubes were kept in dark for 30 minutes and absorbance or optical density was measured using a UV-Vis spectrophotometer. The wavelength was set to $517 \mathrm{~nm}$. Along with samples, control absorbance was also taken. The scavenging activity can be determined by the formula

Scavenging activity $(\%)=\left[\frac{A-B}{A}\right] * 100$

Where A is control absorbance, and $\mathrm{B}$ is the absorbance of DPPH and substrate (Ur Rehman et al., 2020).

\section{Vitamin $C$ content}

The volumetric titration method is employed for the determination of ascorbic acid. In a conical flask $5 \mathrm{~mL}$ of standard ascorbic acid $(100 \mu \mathrm{g} / \mathrm{ml})$ was added which contain $10 \mathrm{ml}$ $4 \%$ oxalic acid and was titrated against the 2,6-dichlorophenol indophenols dye. The appearance and persistence of pink color were taken as the end point.

The amount of dye consumed (V1 ml) is equivalent to the amount of ascorbic acid. In a conical flask $5 \mathrm{~mL}$ of sample (prepared by taking $5 \mathrm{~g}$ of juice in $100 \mathrm{ml} 4 \%$ oxalic acid) was added along with $10 \mathrm{~mL}$ of $4 \%$ oxalic acid and titrated against the dye ( $\mathrm{V} 2 \mathrm{ml})$. The amount of ascorbic acid was calculated using the formula (Rekha et al., 2012).

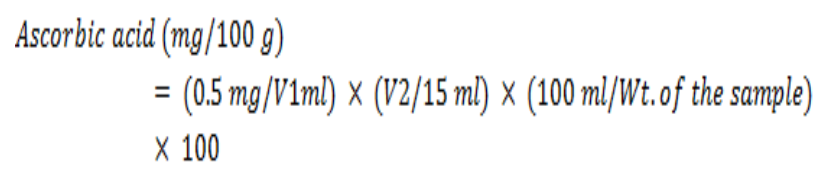

\section{Total phenolic content}

Total phenolic content was determined using Folin ciocalteu reagent. Sample $(0.5 \mathrm{ml})$ was mixed with $2.5 \mathrm{ml}$ of distilled water and 0.5 $\mathrm{ml}$ of $\mathrm{F}-\mathrm{C}$ reagent. Incubate this mixture for 3 minutes and later $2 \mathrm{ml}$ of $20 \%$ sodium carbonate was added. All the tubes were held in a boiling water bath for 1 minute. After attaining room temperature, the absorbance of the mixture was measured using UVSpectrophotometer at $650 \mathrm{~nm}$ wavelength. Total phenolic content was estimated using a standard curve which was plotted using different concentrations of Gallic acid and was expressed as Gallic acid equivalents(GAE)/ml(Ur Rehman et al., 2020).

\section{Reducing sugar content (RSC)}

Reducing sugar content was measured by the DNS method (Khatri, 2020) with some modifications. One gram of 3,5dinitrosalicylic acid(DNSA) was dissolved in $80 \mathrm{ml}$ of $0.5 \mathrm{~N} \mathrm{NaOH}$ at a temperature of $45^{\circ} \mathrm{C}$ along with $30 \mathrm{~g}$ of sodium-potassium tartaric acid. The solution is made upto 100 $\mathrm{ml}$ using distilled water after attaining room temperature. Sample (0.1) was diluted with 10 $\mathrm{ml}$ of distilled water, from that $0.5 \mathrm{ml}$ was taken in a test tube containing $2.5 \mathrm{~mL}$ distilled water. The DNSA reagent $(3 \mathrm{ml})$ was added and heated the content in a boiling water bath for $5 \mathrm{~min}$. Absorbance was measured at 540 $\mathrm{nm}$ using a spectrophotometer. The reducing sugar content was calculated from the calibration curve of standard D-glucose. The results were expressed as $\mathrm{mg} \mathrm{D}$-glucose per $\mathrm{ml}$ of the sample

\section{Sensory analysis}

Nine point hedonic scale was adopted for sensory evaluation of wine sample for aroma, taste, after taste, appearance, and overall 
acceptability. Point 9 indicates extremely like;8 very much like;7 moderately like;6 slightly like; 5 neither like nor dislike; 4 slightly dislike; 3 moderately dislike; 2 very much dislike; 1 extremely dislike). A panel with 30 members were chosen for sensory analysis. In ISO standard wine glasses, wines were introduced to panellists, under daylighttype illumination in isolated booths. Water was provided for mouth rinsing to avoid the carryover of after taste. The better the parameter is scored, the greater the mark will be given. As they were asked to highlight the most dominant aroma descriptors of the analyzed wines, the bottom part of the evaluation sheet included the space for the comments of the tasters (Puškaš and Miljić, 2020).

\section{Statistical analysis}

All studies were carried out in triplicate, and all findings were expressed as mean \pm standard Deviation. For statistical analysis, Minitab $^{\circledR}$ 17.3.1program was used. By oneway variance analysis (ANOVA, with Fisher pairwise comparison) with a confidence level of $95 \%$ and Significance level $\alpha=0.05$ (Gorinstein et al., 2001).

\section{Results and Discussion}

\section{Alcohol content}

The highest alcohol content was detected in orange wine and it is $14.94 \pm 0.30 \%$. Mandarin wine contains $14.31 \pm 0.68 \%$, and Kinnow wine contains $14.12 \pm 0.33 \%$ alcohol. The commercial wine sample contains $11.86 \pm 0.20 \%$.The results after grouping information using the Fisher LSD method and 95\% confidence level showed that Kinnow wine and mandarin wine showed no significant difference. At the same time, these two wines and orange wine are significantly different from commercial wine. Alcohol content decreases with ageing due to evaporation, so commercial wine sample contained less alcohol content compared to young wines (Singleton et al., 1963).

\section{Reducing sugar}

Reducing sugar content of wines were in the order that Mandarin wine has more compared to Kinnow wine. The commercial wine sample contains the least amount of reducing sugar. It is about $22.03 \pm 0.36 \mathrm{mg} / \mathrm{ml}$. The amount of reducing sugar was $30.15 \pm 0.76$, $27.47 \pm 0.69$ and $23.25 \pm 0.48 \quad \mathrm{mg} / \mathrm{ml}$ respectively for Mandarin, Kinnow, and Orange wine. The results indicate that all wines are significantly different from each other and orange wine is having reducing sugar content comparable to commercial wine sample.

\section{Antioxidant activity}

Antioxidant activity is highest for orange wine samples even more than the commercial sample. It showed $85.62 \pm 0.79 \%$ antioxidant activity. The activity of mandarin wine is $75.09 \pm 1.57 \%$ and Kinnow wine has $71.02 \pm 1.48 \%$. The antioxidant activity of commercial wine is $80.52 \pm 1.79 \%$. The mandarin wine and Kinnow wine are significantly different from each other and these are different from control and orange wine.

\section{Total phenolic content}

The total phenolic content of orange wine is $151.62 \pm 1.28(\mathrm{GAE}) / \mathrm{ml}$, for Mandarin wine, it is $137.22 \pm 1.28(\mathrm{GAE}) / \mathrm{ml}$ and for Kinnow wine it is $129.65 \pm 1.28^{\mathrm{c}}(\mathrm{GAE}) / \mathrm{ml}$. The commercial wine sample contains $137.54 \pm 0.34^{\mathrm{b}}(\mathrm{GAE}) / \mathrm{ml}$. The Fisher pairwise comparison studies showed that no significant difference between commercial wine samples and mandarin wine. The orange wine and 
Kinnow wine are significantly different and also these are significantly different from control and orange wine.

The total phenolic content of orange wines is higher compared to commercial wines (grape wine). These results are following the results of others(Belitz et al., 2004). The contents of total polyphenols were found to be present in all four samples, but the orange wine had more total phenolic content compared to commercial wine. At the same time, the antioxidant activity also follows the same order. It has been proposed that the higher the total polyphenolic value, the greater is the antioxidant activity (Abu-Amsha, Croft, Puddey, Proudfoot, \& Beilin, 1996). The overall phenol content of the studied samples are, thus, correlated with their antioxidant activity, It has been discovered that the maximum total polyphenol content was present in orange wine and their antioxidant activity is considerably highest compared to commercial wine samples. The studies showed that the higher the total phenolic content greater will be the antioxidant activity (Gorinstein et al., 2001). Therefor the results are according to the findings of Gorinstein and Olga Martin Belloso.

Table.1 Color value of different wines

\begin{tabular}{|c|c|c|c|c|}
\hline Parameter & Kinnow & Mandarin & Orange & Commercial \\
\hline $\mathbf{L}^{*}$ & $6.80 \pm 0.14^{\mathrm{ab}}$ & $5.23 \pm 0.11^{\mathrm{c}}$ & $6.90 \pm 0.07^{\mathrm{a}}$ & $5.83 \pm 0.08^{\mathrm{b}}$ \\
\hline $\mathbf{a}^{*}$ & $-1.14 \pm 0.02^{\mathrm{c}}$ & $-1.00 \pm 0.02^{\mathrm{b}}$ & $2.03 \pm 0.04^{\mathrm{d}}$ & $-0.62 \pm 0.05^{\mathrm{a}}$ \\
\hline $\mathbf{b}^{*}$ & $0.17 \pm 0.004^{\mathrm{c}}$ & $1.77 \pm 0.04^{\mathrm{b}}$ & $3.66 \pm 0.08^{\mathrm{a}}$ & $-0.48 \pm 0.07^{\mathrm{d}}$ \\
\hline
\end{tabular}

Fig.1 Alcohol and reducing sugar

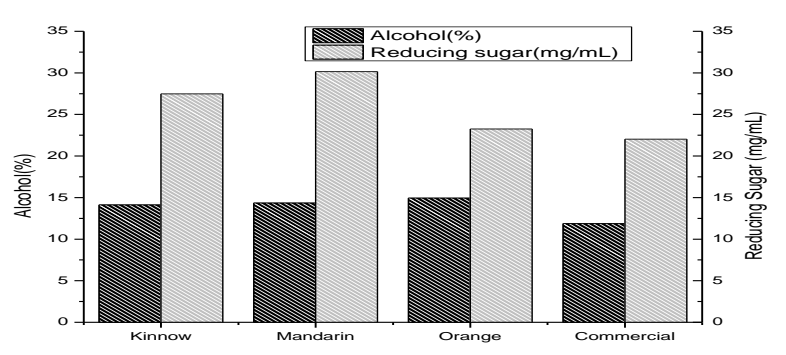

Fig.2 Antioxidant activity and total phenolic content

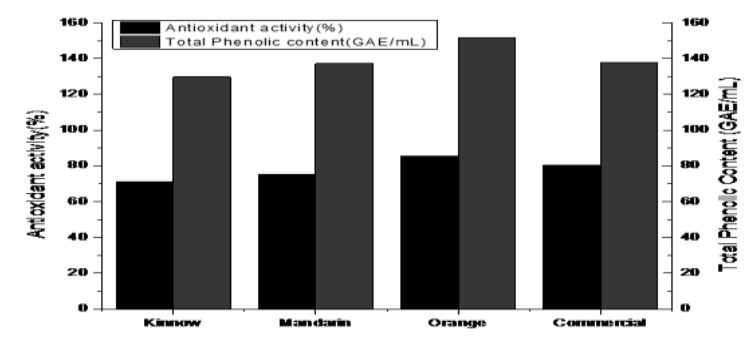


Fig.3 Titrable acidity and Vitamin $\mathrm{C}$ in different wines

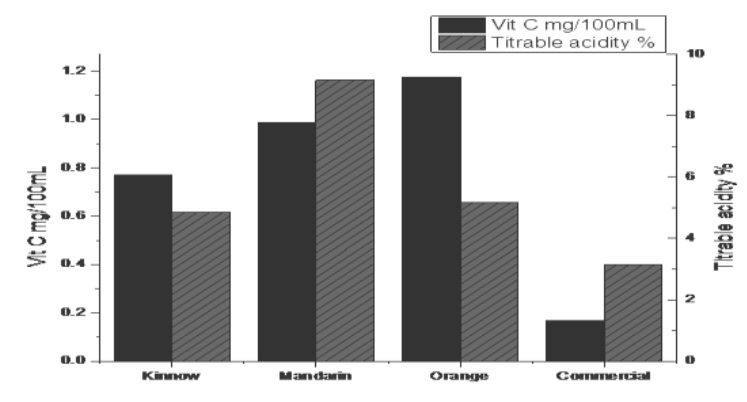

Fig.4 Sensory evaluation

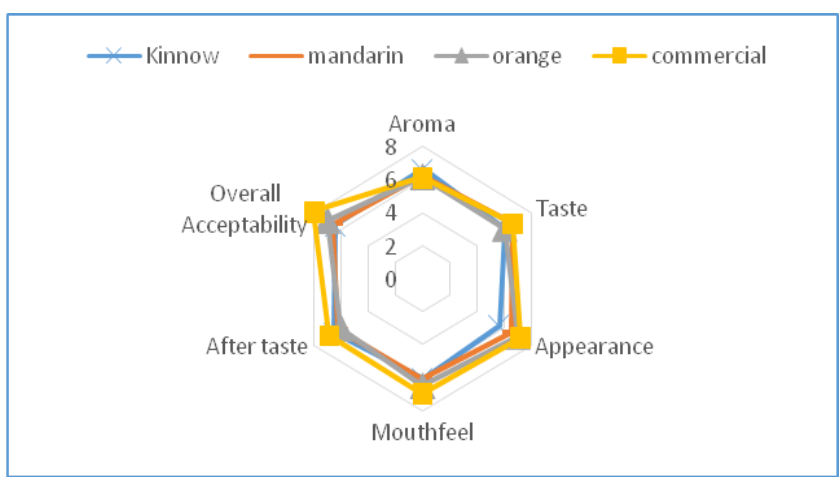

\section{Titrable acidity}

The titrable acidity follows the order, Mandarin wine $>$ Orange wine $>$ Kinnow wine> commercial wine. For orange wine, the value of titrable acidity is $0.66 \pm 0.01 \%$, for Mandarin wine titrable acidity is $1.16 \pm 0.02 \%$ and for Kinnow it is $0.62 \pm 0.02 \%$. The commercial wine sample's titrable acidity is $0.40 \pm 0.01 \%$. All four wines are significantly different from each other. The main components of Citrus fruit juice are organic acids, ascorbic acid and sugars, but their profile and concentration depend on the fruit species and varieties and their concentration is also influenced by the ripening stage, environmental conditions and agronomic practice (Asencio, Serrano, García-Martínez, \& Pretel, 2018). Therefore titrable acidity is different for different variety of orange and commercial wine sample.

\section{Vitamin C}

Vitamin C content is more for orange wine, and it is $120.81 \pm 3.05 \mathrm{mg} / 100 \mathrm{~mL}$. Compared to Kinnow wine vitamin $\mathrm{C}$ is more for Mandarin wine and it is $99.04 \pm 0.79$ $\mathrm{mg} / 100 \mathrm{~mL}$. The vitamin $\mathrm{C}$ content of Kinnow wine is $76.95 \pm 0.76 \mathrm{mg} / 100 \mathrm{~mL}$. The vitamin $\mathrm{C}$ content of commercial wine is $16.93 \pm 0.21$ $\mathrm{mg} / 100 \mathrm{~mL}$. The vitamin $\mathrm{C}$ content of these four wines is significantly different from each other.

Citrus fruits are famous for their antiinflammatory, antitumor antifungal, and antioxidant activities. The most important natural phenolics present in citrus fruits are flavonoids. These have radical scavenging attributes. Ascorbic acid or vitamin $\mathrm{C}$ is a very important antioxidant. It is the most important water-soluble vitamin with effectively scavenging reactive oxygen 
species. Antioxidant value is positively correlated with Ascorbic acid content and total phenolic content. Ascorbic acid can be determined by titrating with an oxidant solution like DCPIP (Dichlorophenol indophenol), Potassium iodate, or bromate. In this study, Vit $\mathrm{C}$ is determined by the titration method. Ascorbic acid reduces dye to a colorless leuco-base. The endpoint is the appearance of pink color. Antioxidant activity is high for wines which are having more ascorbic acid. The results of this study also following the same trend according to the trend (Rekha et al., 2012). The commercial wines are aged wine, comparing to freshly prepared wine samples vitamin $\mathrm{C}$ is less in commercial wine. According to studies done on potatoes by Joseph Hubert, vitamin $\mathrm{C}$ is decreasing with storage (Yamdeu Galani et al., 2017).

The commercially available wines are aged, so also their vitamin $\mathrm{C}$ content will be less compared to the freshly prepared wines. Vitamin $\mathrm{C}$ content of potato can be affected by genotype, harvest date, and growing conditions (Love et al., 2003; Burgos et al., 2009; Cho et al., 2013).So citrus wines made from different species of oranges contains different amount of nutrients. From our study we can conclude that nutrient content is different for different species.

$\mathrm{L}^{*}$ is light, for orange wine, it is more and there is no significant difference between Kinnow and orange wine. There are some similarities between kinnow wine and commercial wine. A negative value of $a^{*}$ indicates green color. There is a significant difference between all wines in the case of $a^{*}$ value. The positive $b^{*}$ values indicate yellow color. The $b^{*}$ value for orange wine, Kinnow wine, and mandarin wine are positive values, but the commercial sample's $b^{*}$ value is negative. The $a^{*}$ and $b^{*}$ value of all the four wines are significantly different from each other. At the same time there are some similarities for Kinnow wine with orange wine and with the commercial sample.

The aroma is more for Kinnow wine compared to mandarin, commercial sample, and orange wine. Mandarin wine is more acceptable to the panelist. The orange wine is good in appearance but commercial wine has better appearance and mouthfeel. The after taste also more for commercial wine. By comparing all the parameters overall acceptability is more for commercial wine. So that the order of preference was in an order commercial wine> orange wine>

In conclusion the citrus wines are a rich source of vitamin $\mathrm{C}$ and total phenolic content. So also the antioxidant activity also more for citrus wines. The nutritional value of four wines are different. According to the studies nutritive values varied based on genotype. The results showed correlation between vitamin $\mathrm{C}$ content and total phenolic content, and at the same time antioxidant activity also positively correlated with these two. The orange wine showed best result, comparing to Kinnow, mandarin and commercial wines. Alcohol content is more for orange wine compared to other three wines. There is no relation between titrable acidity and vitamin $\mathrm{C}$ content. Fermentation has great role in increasing the nutrient content of the fresh juice because of action of yeast cells on juice.

\section{References}

Abu-Amsha, R., Croft, K. D., Puddey, I. B., Proudfoot, J. M., \& Beilin, L. J. (1996). Phenolic content of various beverages determines the extent of inhibition of human serum and low-density lipoprotein oxidation in vitro: Identification and mechanism of action of some cinnamic acid derivatives from 
red wine. Clinical Science. https://doi.org/10.1042/cs0910449

Asencio, A. D., Serrano, M., García-Martínez, S., \& Pretel, M. T. (2018). Organic acids, sugars, antioxidant activity, sensorial and other fruit characteristics of nine traditional Spanish Citrus fruits. European Food Research and Technology, 244(8), 1497-1508. https://doi.org/10.1007/s00217-0183064-X

Belitz, H.-D., Grosch, W., Schieberle, P., Belitz, H.-D., Grosch, W., \& Schieberle, P. (2004). Fruits and Fruit Products. Food Chemistry, 806-861. https://doi.org/10.1007/978-3-66207279-0_19

Contreras, A., Hidalgo, C., Henschke, P. A., Chambers, P. J., Curtin, C., \& Varela, C. (2014). Evaluation of nonSaccharomyces yeasts for the reduction of alcohol content in wine. Applied and Environmental Microbiology, 80(5), 1670-1678. https://doi.org/10.1128/AEM.03780-13

Gorinstein, S., Martín-Belloso, O., Park, Y. S., Haruenkit, R., Lojek, A., Íž, M., ... Trakhtenberg, S. (2001). Comparison of some biochemical characteristics of different citrus fruits. Food Chemistry, 74(3), 309-315. https://doi.org/10.1016/S03088146(01)00157-1

Hayat, K., Abbas, S., Jia, C., Xia, S., \& Zhang, X. (2011). Comparative study on phenolic compounds and antioxidant activity of feutrell's early and kinnow peel extracts. Journal of Food Biochemistry, 35(2), 454-471. https://doi.org/10.1111/j.1745-

4514.2010.00395.x

Hegazy, R. (2013). Post-harvest Situation and Losses in India. https://doi.org/10.6084/m9.figshare.320 6851.v1

Khatri, D. (2020). Reducing Sugar, Total
Phenolic Content, and Antioxidant Potential of Nepalese Plants. 2020.

Mahawar, M. K., Bibwe, B., Jalgaonkar, K., \& Ghodki, B. M. (2019). Mass modeling of kinnow mandarin based on some physical attributes. Journal of Food Process Engineering, 42(5), 1-11. https://doi.org/10.1111/jfpe.13079

Malik, S. K., Rohini, M. R., Kumar, S., Choudhary, R., Pal, D., \& Chaudhury, R. (2012). Assessment of Genetic Diversity in Sweet Orange [Citrus sinensis (L.) Osbeck] Cultivars of India Using Morphological and RAPD Markers. Agricultural Research, 1(4), 317-324.

https://doi.org/10.1007/s40003-0120045-3

National Horticulture Board. (2021). Retrieved from http://nhb.gov.in/StatisticsViewer.aspx? enc $=$ MWoUJibk35dW2g36TUJWAoZq ESmAYFi7h2irlsmjlINTcFl1rG/kLbq8 ZQbWUvuM

Okunowo, W., \& Osuntoki, A. (2007). Quantitation of alcohols in orange wine fermented by four strains of yeast. African J Biochem Res, 1(6), 95-100. Retrieved from http://www.academicjournals.org/journa 1/AJBR/article-full-textpdf/31BF88F9810

Pilone, G. J. (1985). Determination of ethanol in wine by titrimetric and spectrophotometric dichromate methods: Collaborative study. Journal of the Association of Official Analytical Chemists, 68(2), 188-190. https://doi.org/10.1093/jaoac/68.2.188

Puškaš, V. S., \& Miljić, U. D. (2020). The aptitude of commercial yeast strains for lowering the ethanol content of wine. (July 2019), 1489-1498. https://doi.org/10.1002/fsn3.1433

Rekha, C., Poornima, G., Manasa, M., Abhipsa, V., Devi, J. P., Kumar, H. T. 
V., \& Kekuda, T. R. P. (2012). Ascorbic Acid, Total Phenol Content and Antioxidant Activity of Fresh Juices of Four Ripe and Unripe Citrus Fruits. Chemical Science Transactions, 1(2), 303-310.

https://doi.org/10.7598/cst2012.182

Saranraj, P., Sivasakthivelan, P., \& Naveen, M. (2017). Fermentation of fruit wine and its quality analysis: A review. Australian Journal of Science and Technology, 1(2), 85-97. Retrieved from www.aujst.com

Swami, S. B., Thakor, N. J., \& Divate, A. D. (2014). Fruit Wine Production: A Review. Journal of Food Research and Technology, 2(3), 93-100.

Ur Rehman, S., Abbasi, K. S., Qayyum, A., Jahangir, M., Sohail, A., Nisa, S., Sopade, P. (2020). Comparative analysis of citrus fruits for nutraceutical properties. Food Science and Technology, 40(June), 153-157. https://doi.org/10.1590/fst.07519

Yadav, R. (2019). Physico-chemical and Sensory Quality Characteristics of Mandarin (Citrus reticulata Blanco.) Wine as Affected by Initial TSS and Sulphur Dioxide Concentration of the Must. International Journal of Food and Fermentation Technology, 9(1), 41-45. https://doi.org/10.30954/22779396.01.2019.6

Yamdeu Galani, J. H., Mankad, P. M., Shah, A. K., Patel, N. J., Acharya, R. R., \& Talati, J. G. (2017). Effect of Storage Temperature on Vitamin C, Total Phenolics, UPLC Phenolic Acid Profile and Antioxidant Capacity of Eleven Potato (Solanum tuberosum) Varieties. Horticultural Plant Journal, 3(2), 7389. https://doi.org/10.1016/j.hpj.2017.07.00 4

\section{How to cite this article:}

Athira, V. A., and Sinija, V. R. 2021. Comparative Assessment of Wines Developed from Different Varieties of Oranges. Int.J.Curr.Microbiol.App.Sci. 10(01): 3602-3611. doi: https://doi.org/10.20546/ijcmas.2021.1001.425 